\title{
SANKSI HUKUM MEMOTRET ATAU MEREKAM \\ DI LINGKUNGAN RUMAH SAKIT
}

\author{
Oleh : \\ Rosida Diani, SH, MH. \\ (Dosen Tetap Fakultas Hukum Universitas Tamansiswa Palembang)
}

\begin{abstract}
Abstrak
Rumah Sakit adalah institusi pelayanan kesehatan yang menyelenggarakan pelayanan kesehatan perorangan secara paripurna yang menyediakan pelayanan rawat inap, rawat jalan, dan gawat darurat. Di lingkungan rumah sakit setiap orang dilarang untuk mengabadikan semua aktvitas pelayanan kesehatan di rumah sakit, baik itu dilakukan oleh pasien, keluarga pasien, maupun oleh tenaga kesehatan. Apa sanksi hukum bagi seseorang yang memotret atau merekam di lingkungan rumah sakit?

Penelitian ini merupakan penelitian normatif dengan data sekunder berupa peraturan perundang-undangan dan literatur yang berkaitan dengan objek yang diteliti.

Dari hasil penelitian didapatkan bahwa bagi seseorang yang memotret dan/atau merekam segala kegiatan pelayanan kesehatan tanpa izin di areal rumah sakit dapat dikenakan sanksi sebagaimana ditentukan dalam Pasal 48 dan Pasal 51UU No.29 Tahun 2004 tentang Pratik Kedokteran, pasal 40 UU No.36 tahun 1999 tentang Telekomunikasi, UU No.11 tahun 2008 tentang Informasi dan Transaksi Elektronik pada pasal 27, Pasal 45 UU No.19 Tahun 2016
\end{abstract}

Kata kunci : Rumah Sakit, memotret, merekam, sanksi

\section{A. Pendahuluan}

Manusia adalah makhluk Tuhan yang paling sempurna dibandingkan dengan makhluk lainnya. Sebagaimana terdapat di dalam Al- Qur'an di Surah At-Tin ayat 4 : "Sesungguhnya Kami telah menciptakan manusia dalam bentuk yang sebaikbaiknya”.

Menurut Thomas Aquinas "Manusia adalah suatu substansi yang komplit yang terdiri dari badan dan jiwa". ${ }^{34}$ Badan atau fisik manusia ini terdiri dari sel, jaringan, organ dan sistem organ yang teroganisir sempurna menopang kehidupan tubuh manusia. Masing-masing sistem organ saling tergantung satu sama lain, baik secara langsung maupun tidak langsung. Selain secara fisik, manusia juga diciptakan

\footnotetext{
${ }^{34}$ Thomas Aquinas dalam Hardono Hadi, Jati Diri Manusia, Kanisius, Yogyakarta 1996, hlm.
} 
dengan kesempurnaan psikis atau kejiwaan. Ilmu yang mempelajari tentang psikis ini disebut dengan Psikologi. Psikologi membahas tingkah laku manusia dalam hubungannya dengan lingkungannya. ${ }^{35}$

Baik secara fisik maupun psikis, keduanya merupakan hal yang sama pentingnya bagi tubuh manusia, dan masing-masing mempunyai kebutuhan yang berbeda. Secara fisik, manusia membutuhkan asupan gizi untuk tumbuh kembangnya. Gizi adalah proses organisme menggunakan makanan yang dikonsumsi secara normal melalui proses pencernaan, penyerapan, transportasi, penyimpanan, metabolisme, dan pengeluaran zat gizi untuk mempertahankan kehidupan, pertumbuhan dan fungsi normal organ tubuh sertauntuk menghasilkan tenaga. ${ }^{36}$ Sedangkan secara jiwa atau psikis, kebutuhannya bukanlah berupa sesuatu yang dimasukan ke dalam tubuh seperti gizi tetapi lebih merupakan sesuatu yang bersifat abstrak, seperti kebutuhan akan agama, kasih sayang, perhatian, pengakuan, dan lainlain.

Dalam kelangsungan hidupnnya, manusia melakukan berbagai aktivitas sebagai bentuk tanggung jawabnya sebagai makhluk sosial, seperti melaksanakan peran sebagai kepala keluarga, ibu rumah tangga, anak dan lain-lain. Banyaknya rutinitas harian yang berlangsung secara terus menerus tanpa diimbangi dengan pola hidup yang sehat, dapat menjadi salah satu penyebab timbulnya suatu penyakit. ${ }^{37}$

Sebagai salah satu bentuk usaha atau ikhtiar untuk sehat atau kesembuhan penyakitnya adalah dengan berobat. Sebagaimana Allah SWT berfirman :

"Dan barangsiapa berusaha, maka sesungguhnya usahanya itu untuk dirinya sendiri." (Al-Ankabut 6)

Serta berdasarkan riwayat Abu Darda' Radhiyallahu 'Anhu ia berkata: Rasulullah Shalallahu 'Alaihi Wassalam bersabda:

"Sesungguhnya Allah menurunkan penyakit beserta obatnya, dan Dia telah menetapkan bagi setiap penyakit obatnya, maka janganlah berobat dengan perkara yang haram."(H.R Abu Dawud No:3372)

${ }^{35}$ Dakir, Dasar-Dasar Psikologi. Pustaka Pelajar. Yogyakarta, 1993

${ }^{36}$ Djoko Pekik Irianto, Panduan Gizi Lengkap, Penerbit Andi, Yogyakarta, 2006, hlm. 2

37 Penyakit adalah suatu keadaan abnormal dari tubuh atau pikiran yang menyebabkan ketidaknyamanan, disfungsi atau kesukaran terhadap orang yang dipengaruhinya. Untuk menyembuhkan penyakit, orang-orang biasa berkonsultasi dengan seorang dokter. (wikipedia https://id.wikipedia.org/wiki/Penyakit, diakses pada 19 november 2018) 
Rumah sakit merupakan salah satu tempat dimana seseorang yang sakit berikhtiar untuk menyembuhkan penyakitnya. Definisi Rumah Sakit adalah institusi pelayanan kesehatan yang menyelenggarakan pelayanan kesehatan perorangan secara paripurna yang menyediakan pelayanan rawat inap, rawat jalan, dan gawat darurat. ${ }^{38}$ Sehingga dari definisi tersebut, diketahui bahwa Rumah Sakit mempunyai tugas memberikan pelayanan kesehatan perorangan secara paripurna. ${ }^{39}$ Penyediaan rumah sakit merupakan tanggung jawab dari Pemerintah pusat dan Pemerintah daerah. ${ }^{40}$

Saat seseorang menggunakan pelayanan kesehatan dirumah sakit maka dia disebut sebagai pasien. ${ }^{41}$ Pasien ini dapat merupakan pasien rawat inap atau pasien rawat jalan. Sejalan dengan perkembangan dunia teknologi sekarang ini, dimana telepon seluler bukanlah merupakan barang yang mahal lagi, maka pasien kerap kali melakukan hal-hal yang mungkin menurut dirinya adalah hal biasa, sebagai bentuk mengekspresikan eksistensi diri, namun ternyata hal tersebut dapat berujung pada sanksi hukum. Salah satu contohnya adalah perbuatan pasien yang memotret atau merekam aktivitasnya saat menjadi pasien disatu rumah sakit, kemudian mempostingnya ke media sosial. Berdasarkan surat himbauan dari Perhimpunan Rumah Sakit Seluruh Indonesia) nomor : 987/1A/PP.PERSI/II/2018, tentang larangan untuk memfoto atau merekam di area rumah sakit. Maka perbuatan pasien yang memfoto dan merekam di lingkungan Rumah Sakit telah melakukan pelanggaran terhadap ketentuan yang berlaku di Rumah Sakit.

Sehingga di dalam penelitian ini, akan diteliti mengenai Apakah sanksi yang akan diterima oleh pasien atau keluarga pasien yang memotret dan/atau merekam segala aktivitas di Rumah Sakit tanpa izin dari petugas?

\section{B. Metode penelitian}

Penelitian ini merupakan penelitian hukum normatif. Penelitian hukum normatif adalah penelitian hukum yang meletakkan hukum sebagai sebuah bangunan

\footnotetext{
${ }^{38}$ Pasal 1 angka 1 UU No.44 Tahun 2009 tentang Rumah Sakit.

${ }^{39}$ Pelayanan Kesehatan Paripurna adalah pelayanan kesehatan yang meliputi promotif, preventif, kuratif, dan rehabilitatif. (Pasal 1 angka 3 UU No.44 Tahun 2009 tentang Rumah Sakit)

${ }^{40}$ Pasal 6 UU No.44 Tahun 2009 tentang Rumah Sakit.

41 Pasien adalah setiap orang yang melakukan konsultasi masalah kesehatannya untuk memperoleh pelayanan kesehatan yang diperlukan, baik secara langsung maupun tidak langsung di Rumah Sakit.
} 
sistem norma. Sistem norma yang dimaksud adalah mengenai asas-asas, norma, kaidah dari peraturan perundangan putusan pengadilan, perjanjian serta doktrin (ajaran). ${ }^{42}$

\section{Pembahasan}

Rumah Sakit adalah institusi pelayanan kesehatan yang menyelenggarakan pelayanan kesehatan perorangan secara paripurna yang menyediakan pelayanan rawat inap, rawat jalan, dan gawat darurat. ${ }^{43}$ Dilihat dari jenis pelayanannya, Rumah Sakit dibagi menjadi dua macam, yaitu Rumah Sakit dikategorikan dalam Rumah Sakit Umum dan Rumah Sakit Khusus. Rumah Sakit Umum adalah rumah sakit yang memberikan pelayanan kesehatan pada semua bidang dan jenis penyakit. Sedangkan Rumah Sakit Khusus adalah rumah sakit yang memberikan pelayanan utama pada satu bidang atau satu jenis penyakit tertentu berdasarkan disiplin ilmu, golongan umur, organ, jenis penyakit, atau kekhususan lainnya. ${ }^{44}$

Berdasarkan pengelolaannya Rumah Sakit dapat dibagi menjadi Rumah Sakit publik dan Rumah Sakit privat. Rumah Sakit publik dapat dikelola oleh Pemerintah, Pemerintah Daerah, dan badan hukum yang bersifat nirlaba. Rumah Sakit publik yang dikelola Pemerintah dan Pemerintah Daerah diselenggarakan berdasarkan pengelolaan Badan Layanan Umum atau Badan Layanan Umum Daerah sesuai dengan ketentuan peraturan perundang-undangan. Rumah Sakit publik yang dikelola Pemerintah dan Pemerintah Daerah tidak dapat dialihkan menjadi Rumah Sakit privat. Rumah Sakit privat yang dikelola oleh badan hukum didirikan dengan tujuan profit yang berbentuk Perseroan Terbatas atau Persero. ${ }^{45}$

Berdasarkan jenjangnya, rumah sakit umum dibagi menjadi :

a. Rumah Sakit umum kelas A;

b. Rumah Sakit umum kelas B

c. Rumah Sakit umum kelas C;

d. Rumah Sakit umum kelas D

${ }^{42}$ Mukti Fajar ND dan Yulianto Achmad, Dualisme Penelitian Hukum Normatif dan Empiris, Pustaka Pelajar, Yogyakarta, 2013, hlm.34

${ }_{43}^{43}$ Pasal 1 angka 1 UU No.44 Tahun 2009 tentang Rumah Sakit.

${ }^{44}$ Pasal 18 dan 19 UU No.44 Tahun 2009 tentang Rumah Sakit

${ }^{45}$ Pasal 20 dan 21 UU No.44 Tahun 2009 tentang Rumah Sakit 
Sedangkan untuk Rumah Sakit khusus, berdasarkan jenjangnya dibagi menjadi :

a. Rumah Sakit khusus kelas A;

b. Rumah Sakit khusus kelas B;

c. Rumah Sakit khusus kelas C

Rumah sakit sebagai institusi yang merupakan subjek hukum, di dalam dirinya melekat hak dan kewajiban. Dalam kaitannya dengan kegiatan yang dilakukan Rumah Sakit, maka akan terdapat dua sisi tanggung jawab, yaitu kewajiban yang terletak pada sisi Rumah Sakit itu sendiri dan kewajiban yang menjadi beban Pasien yang disebut sebagai hak Rumah Sakit.

Dalam ilmu hukum, pengertian hak menurut Sudikno Mertokusumo, adalah kepentingan yang dilindungi oleh hukum. Sedangkan kepentingan adalah tuntutan yang diharapkan untuk dipenuhi. Kepentingan pada hakikatnya mengandung kekuasaan yang dijamin dan dilindungi oleh hukum dalam melaksanakannya. ${ }^{46}$ Pada dasarnya hak bersumber dari tiga hal, yaitu : ${ }^{47}$

1) Kodrat manusia sebagai makhluk ciptaan Tuhan YME, atau yang disebut hak asasi

2) Hak yang lahir dari hukum, atau disebut hak hukum, misalnya hak memberikan suara dalam pemilu

3) Hak yang lahir dari hubungan hukum, misalnya hak dalam perjanjian

Hak dan kewajiban yang melekat antara Rumah Sakit dan Pasien termasuk dalam hak yang bersumber dari hubungan hukum. Hubungan hukum adalah hubungan yang diatur oleh hukum. ${ }^{48}$ Hubungan hukum dapat terjadi antar sesama subjek hukum. Dapat terjadi antara seseorang dengan orang lain, atau seseorang dengan badan hukum, atau badan hukum dengan badan hukum. Hubungan hukum antara Rumah Sakit dengan pasien, merupakan hubungan antara subjek hukum manusia dengan badan hukum.

\footnotetext{
${ }^{46}$ Sudikno Mertokusumo, Mengenal Hukum Suatu Pengantar, Liberty, Yogyakarta, 1986

47 Meilany, dalam Lukman Santoso, Hak dan Kewajiban Hukum Nasabah Bank, Pustaka Yustisia, Yogyakarta, 2011, hlm.90

${ }^{48}$ Peter Mahmud Marzuki, Pengantar Ilmu Hukum, Kencana, 2013, hlm.216
} 
Ada beberapa hak dan kewajiban dari Rumah Sakit sebagai institusi yang memberikan pelayanan kesehatan kepada masyarakat. Kewajiban Rumah Sakit yaitu: a. memberikan informasi yang benar tentang pelayanan Rumah Sakit kepada masyarakat;

b. memberi pelayanan kesehatan yang aman, bermutu, antidiskriminasi, dan efektif dengan mengutamakan kepentingan pasien sesuai dengan standar pelayanan Rumah Sakit;

c. memberikan pelayanan gawat darurat kepada pasien sesuai dengan kemampuan pelayanannya;

d. berperan aktif dalam memberikan pelayanan kesehatan pada bencana, sesuai dengan kemampuan pelayanannya;

e. menyediakan sarana dan pelayanan bagi masyarakat tidak mampu atau miskin;

f. melaksanakan fungsi sosial antara lain dengan memberikan fasilitas pelayanan pasien tidak mampu/miskin, pelayanan gawat darurat tanpa uang muka, ambulan gratis, pelayanan korban bencana dan kejadian luar biasa, atau bakti sosial bagi misi kemanusiaan;

g. membuat, melaksanakan, dan menjaga standar mutu pelayanan kesehatan di Rumah Sakit sebagai acuan dalam melayani pasien;

h. menyelenggarakan rekam medis;

i. menyediakan sarana dan prasarana umum yang layak antara lain sarana ibadah, parkir, ruang tunggu, sarana untuk orang cacat, wanitamenyusui, anak-anak, lanjut usia;

j. melaksanakan sistem rujukan;

k. menolak keinginan pasien yang bertentangan dengan standar profesi dan etika serta peraturan perundang-undangan;

1. memberikan informasi yang benar, jelas dan jujur mengenai hak dan kewajiban pasien;

m. menghormati dan melindungi hak-hak pasien;

n. melaksanakan etika Rumah Sakit;

o. memiliki sistem pencegahan kecelakaan dan penanggulangan bencana;

p. melaksanakan program pemerintah di bidang kesehatan baik secara regional maupun nasional; 
q. membuat daftar tenaga medis yang melakukan praktik kedokteran atau kedokteran gigi dan tenaga kesehatan lainnya;

r. menyusun dan melaksanakan peraturan internal Rumah Sakit (hospital by laws);

s. melindungi dan memberikan bantuan hukum bagi semua petugas Rumah Sakit dalam melaksanakan tugas; dan

t. memberlakukan seluruh lingkungan rumah sakit sebagai kawasan tanpa rokok. ${ }^{49}$

Adapun hak-hak dari Rumah Sakit adalah :

a. menentukan jumlah, jenis, dan kualifikasi sumber daya manusia sesuai dengan klasifikasi Rumah Sakit;

b. menerima imbalan jasa pelayanan serta menentukan remunerasi, insentif, dan penghargaan sesuai dengan ketentuan peraturan perundang-undangan;

c. melakukan kerjasama dengan pihak lain dalam rangka mengembangkan pelayanan;

d. menerima bantuan dari pihak lain sesuai dengan ketentuan peraturan perundangundangan;

e. menggugat pihak yang mengakibatkan kerugian;

f. mendapatkan perlindungan hukum dalam melaksanakan pelayanan kesehatan;

g. mempromosikan layanan kesehatan yang ada di Rumah Sakit sesuai dengan ketentuan peraturan perundang-undangan; dan

h. mendapatkan insentif pajak bagi Rumah Sakit publik dan Rumah Sakit yang ditetapkan sebagai Rumah Sakit pendidikan. ${ }^{50}$

Saat berbicara mengenai hak dan kewajiban Rumah Sakit, maka akan berkaitan juga dengan hak dan kewajiban pasien. Setiap pasien mempunyai kewajiban terhadap Rumah Sakit ataspelayanan yang diterimanya. Kewajiban ini antara lain $:^{51}$

1) mematuhi ketentuan yang berlaku di Rumah Sakit,

2) memberikan imbalan jasa atas pelayanan yang diterima di Rumah Sakit sesuai dengan ketentuan yang berlaku,

\footnotetext{
${ }^{49}$ Pasal 29 UU No.44 Tahun 2009 tentang Rumah Sakit

${ }^{50}$ Pasal 30 UU No.44 Tahun 2009 tentang Rumah Sakit

51 Pasal 31 UU No.44 Tahun 2009 tentang Rumah Sakit
} 
3) memberikan informasi yang lengkap dan jujur tentang masalah kesehatannya kepada tenaga kesehatan di Rumah Sakit, dan

4) mematuhi kesepakatan dengan Rumah Sakit.

Adapun yang menjadi hak pasien adalah sebagai berikut:

a. Setiap pasien mempunyai hak memperoleh informasi mengenai tata tertib dan peraturan yang berlaku di Rumah Sakit;

b. memperoleh informasi tentang hak dan kewajiban pasien;

c. memperoleh layanan yang manusiawi, adil, jujur, dan tanpa diskriminasi;

d. memperoleh layanan kesehatan yang bermutu sesuai dengan standar profesi dan standar prosedur operasional;

e. memperoleh layanan yang efektif dan efisien sehingga pasien terhindar dari kerugian fisik dan materi;

f. mengajukan pengaduan atas kualitas pelayanan yang didapatkan;

g. memilih dokter dan kelas perawatan sesuai dengan keinginannya dan peraturan yang berlaku di Rumah Sakit;

h. meminta konsultasi tentang penyakit yang dideritanya kepada dokter lain yang mempunyai Surat Izin Praktik (SIP) baik di dalam maupun di luar Rumah Sakit;

i. mendapatkan privasi dan kerahasiaan penyakit yang diderita termasuk data-data medisnya;

j. mendapat informasi yang meliputi diagnosis dan tata cara tindakan medis, tujuan tindakan medis, alternatif tindakan, risiko dan komplikasi yang mungkin terjadi, dan prognosis terhadap tindakan yang dilakukan serta perkiraan biaya pengobatan;

k. memberikan persetujuan atau menolak atas tindakan yang akan dilakukan oleh tenaga kesehatan terhadap penyakit yang dideritanya;

1. didampingi keluarganya dalam keadaan kritis;

m. menjalankan ibadah sesuai agama atau kepercayaan yang dianutnya selama hal itu tidak mengganggu pasien lainnya;

n. memperoleh keamanan dan keselamatan dirinya selama dalam perawatan di Rumah Sakit;

o. mengajukan usul, saran, perbaikan atas perlakuan Rumah Sakit terhadap dirinya; 
p. menolak pelayanan bimbingan rohani yang tidak sesuai dengan agama dan kepercayaan yang dianutnya;

q. menggugat dan/atau menuntut Rumah Sakit apabila Rumah Sakit diduga memberikan pelayanan yang tidak sesuai dengan standar baik secara perdata ataupun pidana; dan

r. mengeluhkan pelayanan Rumah Sakit yang tidak sesuai dengan standar pelayanan melalui media cetak dan elektronik sesuai dengan ketentuan peraturan perundangundangan.

Perbuatan pasien atau keluarga pasien yang memotret dan/atau merekam di lingkungan rumah sakit merupakan perbuatan pelanggaran ketentuan rumah sakit. Saat ini disetiap Rumah Sakit, tertempel di dinding beberapa sudut Rumah Sakit, ditempat-tempat yang mudah terbaca oleh setiap orang yang berlalu lalang mengenai ketentuan larangan memotret atau merekam kegiatan yang ada di Rumah Sakit.

Berikut contoh pengumuman mengenai larangan memotret atau merekam di area Rumah Sakit :
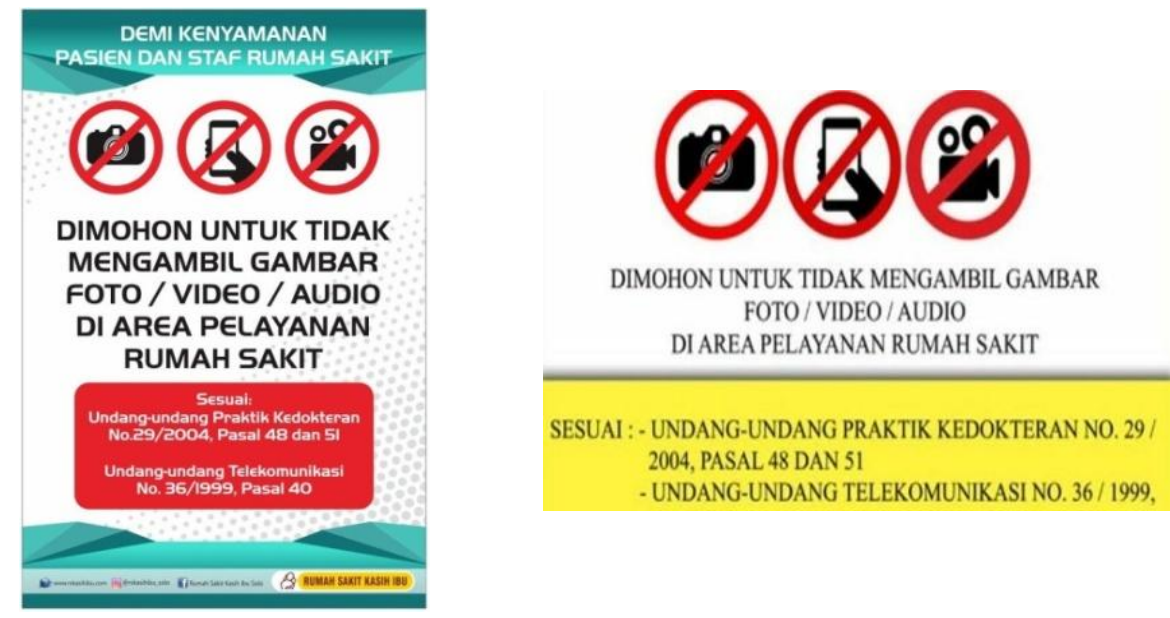

Dalam poster-poster yang ditempel atau dipasang di area Rumah Sakit, tertera beberapa Dasar hukum larangan memotret atau merekam, yaitu:

a. UU No.29 Tahun 2004 tentang Pratik Kedokteran, yaitu pada Pasal 48 dan Pasal 51.

Pasal 48 berisi tentang kewajiban dari dokter atau dokter gigi untuk menyimpan rahasia kedokteran. Rahasia Rahasia kedokteran dapat dibuka hanya untuk kepentingan kesehatan pasien, memenuhi permintaan aparatur penegak 
hukum dalam rangka penegakan hukum, permintaan pasien sendiri, atau berdasarkan ketentuan perundang-undangan.

Pasal 51 mengatur bahwa Dokter atau dokter gigi dalam melaksanakan praktik kedokteran mempunyai beberapa kewajiban salah satunya, dalam point "c" yaitu merahasiakan segala sesuatu yang diketahuinya tentang pasien, bahkan juga setelah pasien itu meninggal dunia;

Larangan dalam UU No.29 Tahun 2004 tentang Praktik Kedokteran, pada pasal 48 dan Pasal 51 merupakan larangan yang ditujukan bagi dokter atau dokter gigi dalam merahasiakan segala sesuatu tentang pasien. Salah satu bentuk menjaga kerahasiaan pasien adalah dengan tidak memotret atau merekam pasien selama pasien berada di area Rumah Sakit.

b. UU No.36 tahun 1999 tentang Telekomunikasi, yaitu pada pasal 40 .

Pasal 40 mengatur mengenai larangan bagi setiap orang melakukan kegiatan penyadapan atas informasi yang disalurkan melalui jaringan telekomunikasi dalam bentuk apapun.

Perbuatan dokter, atau tenaga medis lainnya, pasien atau keluarga pasien, yang memotret atau merekam di lingkungan Rumah Sakit tanpa izin dari pihak yang berwenang untuk itu, maka dapat dikenakan pasal ini karena dapat dikategorikan sebagai perbuatan penyadapan.

Definisi penyadapan dapat kita temukan dalam Pasal Penjelasan Pasal 31 Ayat (1) Undang-Undang Nomor 11 Tahun 2008, yaitu :

Penyadapan atau intersepsi adalah kegiatan untuk mendengarkan, merekam, membelokkan,mengubah, menghambat, dan atau mencatat transmisi informasi elektronik dan atau Dokumen elektronik yang bersifat publik, baik menggunakan jaringan kabel komunikasi maupun jaringan nirkabel, seperti elektromagnetis atau Radio.

c. UU No.11 tahun 2008 tentang Informasi dan Transaksi Elektronik, pasal 27

Pasal 27 berisi tentang larangan bagi setiap orang yang sengaja dan hak mendistribusikan dan/atau mentransmisikan dan/atau membuat dapat diaksesnya Informasi Elektronik dan/atau Dokumen Elektronik yang memiliki muatan yang melanggar kesusilaan, memiliki muatan perjudian, memiliki muatan penghinaan dan/atau pencemaran nama baik dan memiliki muatan pemerasan dan/atau pengancaman. 
Perbuatan seorang pasien, misalnya yang memotret atau merekam di lingkungan Rumah Sakit dengan tujuan untuk menunjukan keburukan, atau kurang memuaskannya pelayanan di Rumah Sakit, kemudian mempostingnya ke media sosial, dapat memenuhi unsur pasal ini yaitu mengenai pencemaran nama baik. Atau dapat juga misalnya seorang tenaga medis yang merekam suatu tindakan medis yang seharusnya dapat diduga itu merupakan bagian dari privasi pasien, dan dapat dikategorikan memiliki muatan kesusilaan, maka dapat juga dikenakan pasal ini.

Larangan pada pasal 27 ini bukan hanya ditujukan bagi pasien, atau keluarga pasien saja, tetapi bagi semua pihak, termasuk tenaga medis.

d. UU No.19 Tahun 2016 Perubahan UU No.11 tahun 2008 tentang Informasi dan Transaksi Elektronik

Ada beberapa aturan dalam UU No.19 Tahun 2016 yang diubah, yang dapat diterapkan kepada siapa saja yang memotret atau merekam di lingkungan Rumah Sakit, yaitu sebagai berikut:

"Pasal 31

(1) Setiap Orang dengan sengaja dan tanpa hak atau melawan hukum melakukan intersepsi atau penyadapan atas Informasi Elektronik dan/atau Dokumen Elektronik dalam suatu Komputer dan/atau Sistem Elektronik tertentu milik Orang lain.

(2) Setiap Orang dengan sengaja dan tanpa hak atau melawan hukum melakukan intersepsi atas transmisi Informasi Elektronik dan/atau Dokumen Elektronik yang tidak bersifat publik dari, ke, dan di dalam suatu Komputer dan/atau Sistem Elektronik tertentu milik Orang lain, baik yang tidak menyebabkan perubahan apa pun maupun yang menyebabkan adanya perubahan, penghilangan, dan/atau penghentian Informasi Elektronik dan/atau Dokumen Elektronik yang sedang ditransmisikan.

(3) $\ldots$

(4) $\ldots$

Setiap orang yang memotret atau merekam di lingkungan Rumah Sakit dapat dikenakan sanksi hukum, apabila memenuhi ketentuan pada pasal 31 ayat (1) dan 
(2) di atas. Sanksi hukum perbuatan ini diatur di dalam Pasal 45 UU No.19 Tahun 2016, yaitu :

(1) Setiap Orang yang dengan sengaja dan tanpa hak mendistribusikan dan/atau mentransmisikan dan/atau membuat dapat diaksesnya Informasi Elektronik dan/atau Dokumen Elektronik yang memiliki muatan yang melanggar kesusilaan sebagaimana dimaksud dalam Pasal 27 ayat (1) dipidana dengan pidana penjara paling lama 6 (enam) tahun dan/atau denda paling banyak Rp1.000.000.000,00 (satu miliar rupiah).

(2) Setiap Orang yang dengan sengaja dan tanpa hak mendistribusikan dan/atau mentransmisikan dan/atau membuat dapat diaksesnya Informasi Elektronik dan/atau Dokumen Elektronik yang memiliki muatan perjudian sebagaimana dimaksud dalam Pasal 27 ayat (2) dipidana dengan pidana penjara paling lama 6 (enam) tahun dan/atau denda paling banyak Rp1.000.000.000,00(satu miliar rupiah).

(3) Setiap Orang yang dengan sengaja dan tanpa hak mendistribusikan dan/atau mentransmisikan dan/atau membuat dapat diaksesnya Informasi Elektronik dan/atau Dokumen Elektronik yang memiliki muatan penghinaan dan/atau pencemaran nama baik sebagaimana dimaksud dalam Pasal 27 ayat (3) dipidana dengan pidana penjara paling lama 4 (empat) tahun dan/atau denda paling banyak Rp750.000.000,00 (tujuh ratus lima puluh juta rupiah).

(4) Setiap Orang yang dengan sengaja dan tanpa hak mendistribusikan dan/atau mentransmisikan dan/atau membuat dapat diaksesnya Informasi Elektronik dan/atau Dokumen Elektronik yang memiliki muatan pemerasan dan/atau pengancaman sebagaimana dimaksud dalam Pasal 27 ayat (4) dipidana dengan pidana penjara paling lama 6 (enam) tahun dan/atau denda paling banyak Rp1.000.000.000,00 (satu miliar rupiah).

(5) Ketentuan sebagaimana dimaksud pada ayat (3) merupakan delik aduan.

Pemberian sanksi bagi pasien, keluarga pasien atau tenaga kesehatan yang memotret segala aktivitas pelayanan kesehatan di lingkungan Rumah Sakit, merupakan perwujudan pelanggaran kewajiban. Disisi lain ini merupakan hak dari Rumah sakit. Dilekatkan dengan sanksi agar hak itu mempunyai arti. Sebagaimana 
menurut Bentham, "hak tidak mempunyai arti apa-apa jika tidak ditunjang oleh undang-undang"52 bentham juga menambahkan bahwa "hak untuk dapat dilaksanakan harus dituangkan ke dalam undang-undang”. Dari pandangan inilah terbentuk pandangan yang menyatakan bahan hak merupakan bentukan hukum. ${ }^{53}$

Tindakan seorang pasien atau keluarga pasien atau tenaga medis, yang memotret dan/atau merekam di lingkungan Rumah Sakit, merupakan bentuk pelanggaran sebagaimana diuraikan di atas. Pelanggaran ini dapat dikenakan sanksi sesuai dengan peraturan perundang-undangan yang berlaku. Dalam ilmu hukum, pemberian sanksi kepada seseorang yang melanggaran aturan merupakan bentuk pertanggung jawaban atas kesalahan.

Suatu tindakan merupakan sesuatu yang dapat dihindari atau dilakukan, artinya seseorang itu dapat memilih atau melakukan atau tidak melakukannya. Apabila seseorang itu tidak dapat atau tidak sanggup menentukan kehendaknya dan tidak bertindak sesuai dengan yang dikehendakinya, maka orang tersebut dianggap tidak normal. Dalamhal tersebut, maka tindakan orang itu tidak dapat dipertanggung jawabkan. ${ }^{54}$ Sehingga apabila seseorang memenuhi kriteria normal, (artinya mampu menentukan kehendak dan sanggup bertindak sesuai dengan kehendaknya), ia memotret dan/atau merekam di lingkungan Rumah sakit, maka dapat dikenakan sanksi sebagai bentuk pertanggung jawaban karena kesalahan.

\section{Penutup}

Seseorang yang memotret dan/atau merekam suatu aktivitas pelayanan kesehatan di rumah sakit tanpa ijin dari petugas, kemudian mengunggah maupun tidak mengunggahnya ke media sosial, maka dapat dikenakan sanksi Pasal 48 dan Pasal 51UU No.29 Tahun 2004 tentang Pratik Kedokteran, pasal 40 UU No.36 tahun 1999 tentang Telekomunikasi, UU No.11 tahun 2008 tentang Informasi dan Transaksi Elektronik pada pasal 27, Pasal 45 UU No.19 Tahun 2016.

\footnotetext{
${ }_{52}^{52}$ Bentham, dalam Peter Mahmud Marzuki, op.cit., hlm.142

${ }^{53}$ Ibid, hlm. 143

${ }^{54} \mathrm{Ibid}, \mathrm{hlm} .219$
} 


\section{DAFTAR PUSTAKA}

Dakir, Dasar-Dasar Psikologi. Pustaka Pelajar. Yogyakarta

Djoko Pekik Irianto, Panduan Gizi Lengkap, Penerbit Andi, Yogyakarta, 2006

Hardono Hadi, Jati Diri Manusia, Kanisius, Yogyakarta 1996

Lukman Santoso, Hak dan Kewajiban Hukum Nasabah Bank, Pustaka Yustisia, Yogyakarta, 2011

Mukti Fajar ND dan Yulianto Achmad, Dualisme Penelitian Hukum Normatif dan Empiris, Pustaka Pelajar, Yogyakarta, 2013

Peter Mahmud Marzuki, Pengantar Ilmu Hukum, Kencana, 2013

Sudikno Mertokusumo, Mengenal Hukum Suatu Pengantar, Liberty, Yogyakarta, 1986

UU No.44 Tahun 2009 tentang Rumah Sakit.

UU No.29 Tahun 2004 tentang Pratik Kedokteran

UU No.36 tahun 1999 tentang TelekomunikasiUU No.19 Tahun 2016 Perubahan UU No.11 tahun 2008 tentang Informasi dan Transaksi Elektronik 